\title{
岩石内部亀裂系のフルカラー可視化法
}

\author{
清水 均*1 ・高橋 学*2 $・$ 浜島良吉 $* 3$
}

\section{A Fullcolored Visualization Method of Stress Induced Microcracks in a Rock}

\author{
Hitoshi SHIMIZU*1, Manabu TAKAHASHI*2 and Ryoukichi HAMAJIMA*3
}

\begin{abstract}
Key words : 三軸圧縮試験 conventional triaxial compression test，亀裂系の分布 distribution of stress induced microcracks, 可視化法 visualization method, 画像表示 image displaying
\end{abstract}

\section{1. は じめに}

「百聞は一見にしかず」という諺があるように，どん なに言葉を尽くしても説明できないことが，1枚の絵を 見せるだけで簡単にわかることがある。これは, 人間が 画像の中の情報を一瞬のうちに取り込久, 解析して理解 する能力を備えているためであると考えられる。また， 画像の中の情報の 1 つである「その対象物が何である 功を判断する基準には，「形」と「色」という $2 つ の$ 手がかりが考えられる。特に, 他の感覚を表す言葉に比 べると, 色の感覚を表す言葉には誰にでも通用する共通 語が最も豊富に存在し，その分類基準が明確である。

このような人間の視覚的判断基準に訴えるべく，地盤 や岩石の龟裂群の観察抢よび解析に扔いて, コンピュー 夕を用いた画像処理や画像表示などの手法が盛んに用い られている。岩盤の地下流体挙動や力学的挙動を解明す るためには, 亀裂系の分布や形状の把握は非常に重要で ある。

しかし今までの手法による亀裂やポアの観察1 は，そ のほとんどが 1 枚の断面画像, あるいは 1 枚の薄片か

*1 埼玉大学大学院理工学研究科 Graduate Student, Faculty of Engineering, Saitama University

*2 地質調査所 Environmental Geology Department, Geological Survey of Japan

*3 埼玉大学工学部建設工学科 Fuculty of Engineering, Saitama University
ら得られる 2 次元的な情報の把握でしかない。一方, すでに医療の分野においては実際の脳や心蔵のデータに 基づいて, それらの精密な 3 次元グラフィックス表示 に成功し, 任意断面の切り出し等によって腫瘍や血流の 状態の把握に貢献している2)。

そこで本文では, 三軸試験を行った稲田花崗岩の供試 体の断面を, 一定のピッチで連続的に CCD カメラを用 いて画像入力し, その断面画像をコンピュータ内部で積

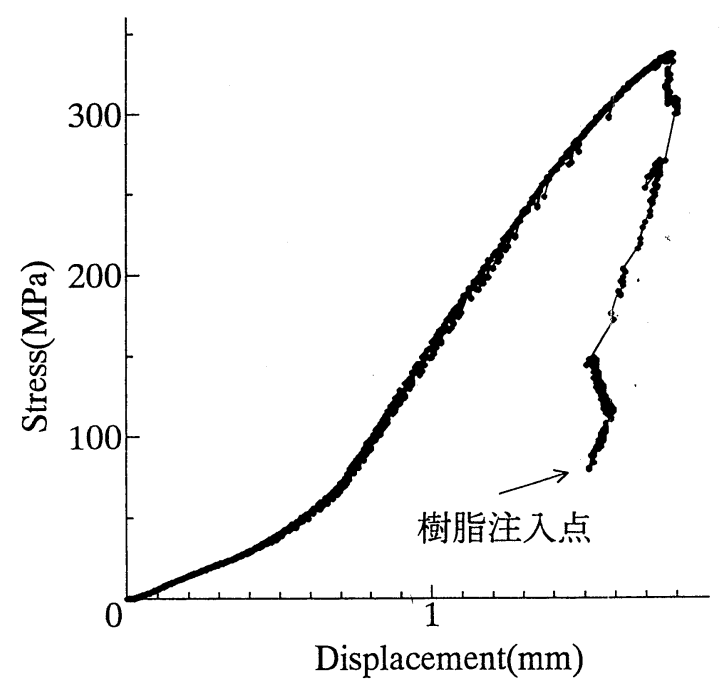

図 - 1 CLASS II 型の変形様式 


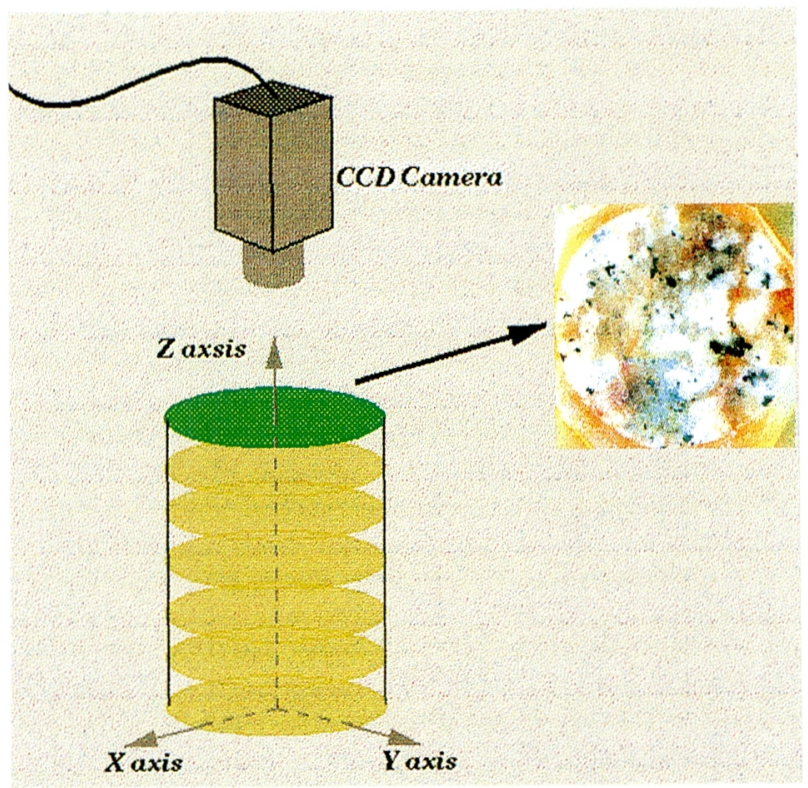

図－2座標軸の設定と断面画像取り込み模式図

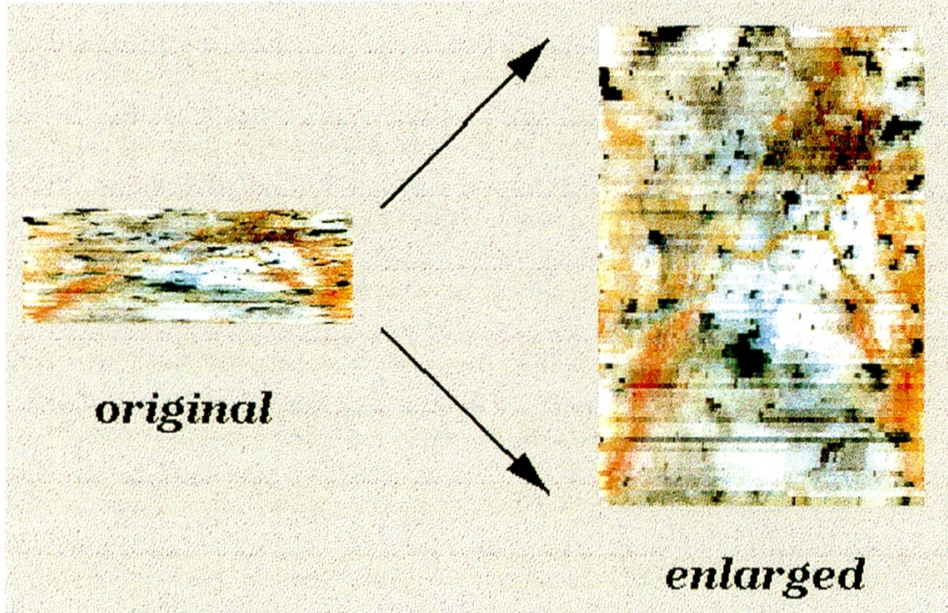

図－3繸方向に拡大した断面図

（Y 軸に垂直，供試体中央部 134 番目の断面） 


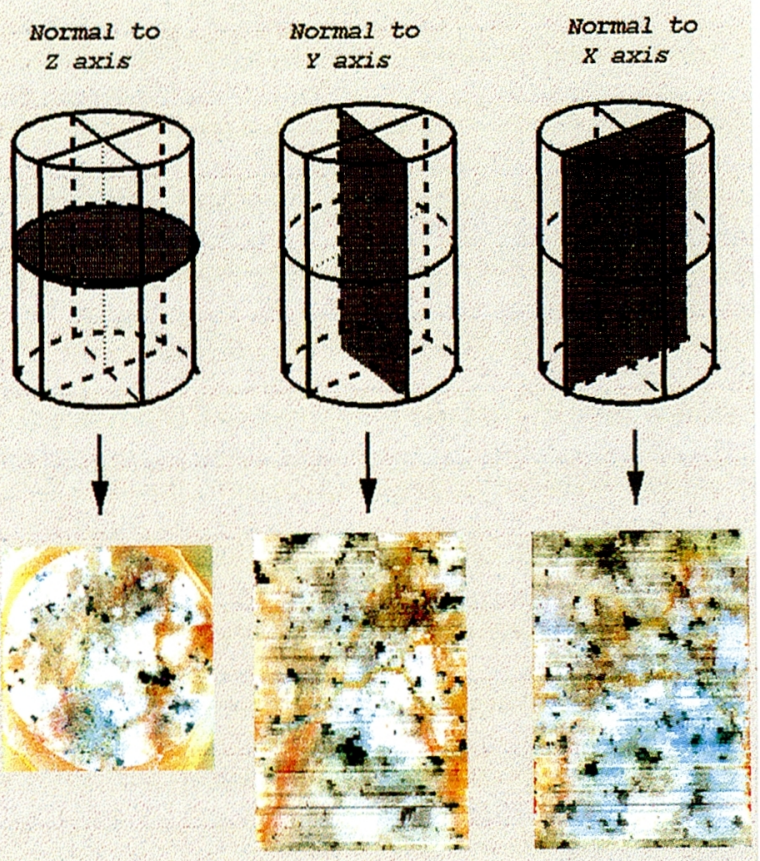

図-4表示可能な断面の方向と位置関係

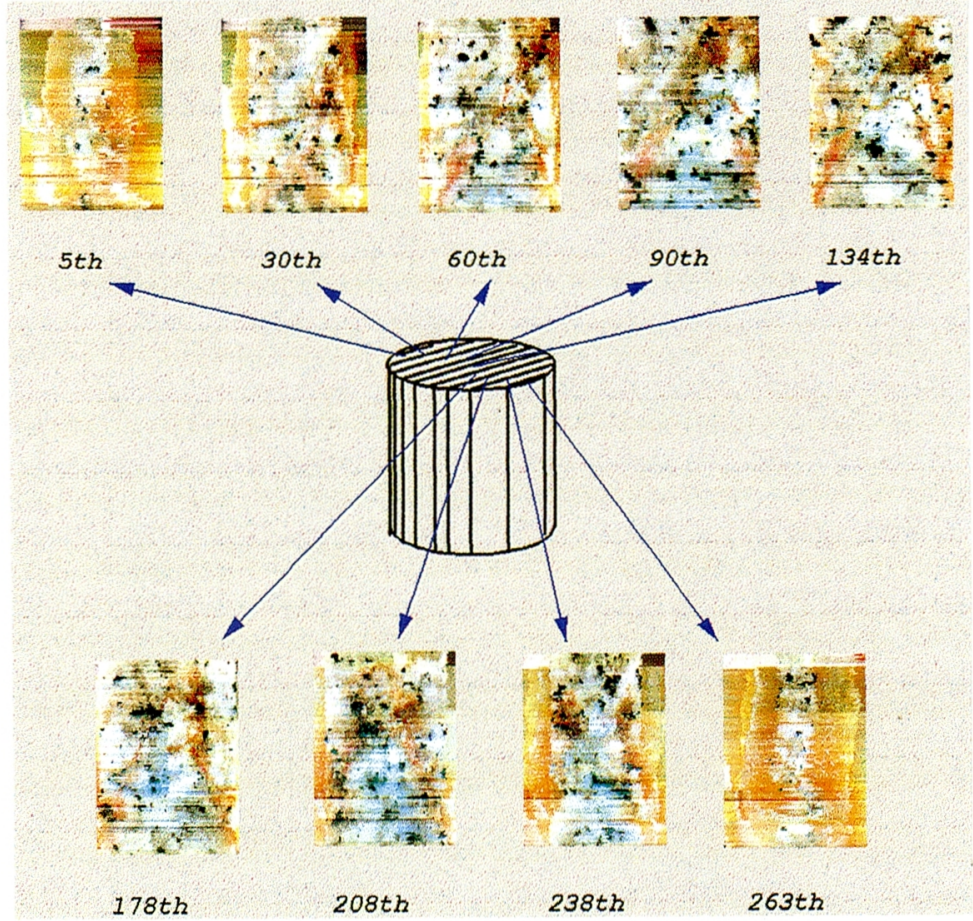

図－5Y 軸に垂直な断面を端部から順に表示した様子 
み重ねることによって亀裂系の画像データを 3 次元構 筑し, フルカラーで内部断面を画像表示する手法が可能 になったので紹介する。

\section{2. 画像表示方法について}

画像表示方法として AVS (Application Visualization System）を用いた。AVS は Xウインドウシステムを ベースとしたビジュアライゼーションツールであり, ワ ークステーションからスーパーコンピュータまであらゆ る環境での稼働が可能なため, 現在コンピュータによる 可視画像化の分野では，標準的なソフトウェアになりつ つある。主要な機能としては，2 次元のイメージデータ に対して処理を施すイメージビューワ，3 次元幾何座標 データの表示を行うジオメトリビューワ，グラフを作成 するグラフビューワ等がある。今回は取り込んだイメー ジデータを 3 次元的に積み重ねて，そこから 2 次元の 断面データをイメージビューワを用いて画像表示するた めにAVSを利用した。

\section{CCD カメラによる断面画像の取り込み}

三軸圧縮応力下におかれた稲田花崗岩の供試体（值径 $30 \mathrm{~mm}$, 高さ $60 \mathrm{~mm}$ )の割れ目系に，赤色顔料で着色さ れた樹脂（シアノアクリレート）を注入する。この際， 供試体は最大強度点を過ぎて变形が応力の減少とともに 減少する，いわゆるCLASS II 型の変形様式（図 - 1) を示している。樹脂固化後，回転型断面研磨機を用いて 供試体断面を研磨していき，ある規定の高さになったら 断面画像を CCD カメラによって，フルカラーでワーク ステーションに取り込む（図-2）。そしてこの後は断 面を $0.5 \mathrm{~mm}$ のピッチで研磨し，上記の作業を繰り返し

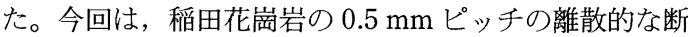
面画像を98枚得ることができた。すなわち，供試体高 さ $60 \mathrm{~mm}$ のうちの $49 \mathrm{~mm}$ 分についての断面画像が得 られたことになる。

\section{AVS を用いた画像データの 3 次元構築}

断面画像は取り込んだ順にAVSを用いて積み重ねら れ，フルカラーの画像データとして 3 次元構築される。 その画像データを縌方向（重ねた断面を貫く方向）にス ライスして画像表示すると, 取り込んだ断面画像とは違 う角度から岩石の内部の状況を確認できる。ただし，取 り込んだ 1 枚の画像データの厚さは，研磨のピッチに かかわらず再構成して積み重ねた画面上ではすべて 1 ピクセルで表現されてしまうため，このままだと縦横の バランスが悪く，見づらいものとなる。そこで，高さ方
向に関して適当な倍率に拡大して表示すると，かなり荒 っぽい印象の画像になってしまうが，視覚的に見やすい 画像となり，供試体内部の亀裂系全体の把握を行うのに 都合が良い（図-3）。

また，図-2の模式図に表したように，3 次元直交座 標系の座標軸を $X, Y, Z$ 軸とすると，それぞれの軸に 垂直な断面をスライスして表示することが可能である。 すなわち，1つの方向から取り込んだ連続的な画像か ら，実際には観察が不可能な他の 2 つの方からの画 像を得ることができる（図-4）。今回使用した画像デ 一夕は， $Z$ 軸方向に垂直な断面が98断面，そして，そ れらの画像から作成される $X$ および $Y$ 軸方向に垂直な 断面は，それぞれ268断面が表示可能である。

図 - 5 は $Y$ 軸方向に垂直な断面を，供試体端部より 5 , $30,60,90,134$ (中央部)，178, 208, 238, 263番目の順に 切り出し，表示した様子を示している。AVSを用いる ことによって，このようにナイフで切り出すような感覚 で供試体の断面画像を簡単に得ることができ，しかも別 の角度, 任意の切り出し位置のフルカラー画像を表示す ることが可能となった。また，図－6に一連の処理をフ ローチャートにして示した。

\section{5. 赤色で表示される領域の持つ意味}

図－5の断面画像において，5，30，238および263番目 等の断面外郭部に見える黄色の部分は実験時に塗布した シリコン樹脂である。内部に存在する赤系統の色で表示 されている部分が，亀裂系に浸透した赤色の樹脂であ る。特に中央部の134番目の断面（図 -3 右側之同一断 面）を見ると，右側上方部と左右下方両外郭部は広い範 囲で面的に赤色樹脂が浸透しているのがわかる。また， 断面を斜めに横断している線形の赤色樹脂も数本確認で きる。

これは, 今回の画像取り込みピッチが $0.5 \mathrm{~mm}$ と荒く なっているために，供試体外側に存在する幅の小さい微 小亀裂やいわゆる破砕帯となっている部分は，それらが 面的に表示され，そして亀裂幅が小さいものは線形のつ ながりとして表示されているものと考えられる。

既述したように，本供試体は図－1のような CLASS II型の挙動を示し, 実験は応力鹵還法によって破壊後領 域まで制御されたものである。樹脂注入は破壊後領域で 載荷を一時中断して行われ，その後 $5 \sim 6$ 時間, 応力を 制御した状態で保持しているので, 赤く着色されている 部分は破壞後領域において樹脂が通った道筋であると同 時に，周辺に拡散，湿潤した範囲をも示していることに なる。したがって，赤く着色表示される部分は，流体の 


\section{花崗岩の三軸試験}

破壤後領域で戠荷中断
赤色顔料を混合した樹脂注入

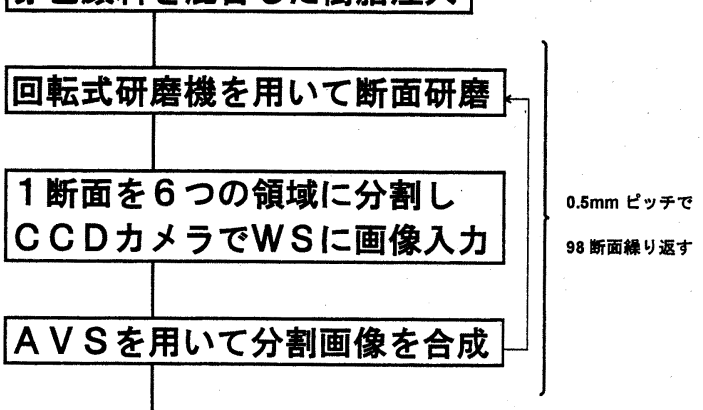

A V S用に作成したモジュール を用いて断面を積み重ねること によってデータの3次元化を行う

\section{$\mathrm{X} ， \mathrm{Y}, \mathrm{Z}$ 軸に垂直な平面における} 任意の位畾のフルカラー画像表示

図-6 岩石の内部の龟裂構造の可視化のフローチャート

通過経路そのものの幅を示しているものではないことに 注意しておかなければならない。シアノアクリレートの ような一般の樹脂では鉱物粒子を潤れさせてしまうの で, 亀裂の幅そのものの把握という意味では, 本手法は 限界があるものと思われる。

フルカラー表示された図（図 $-5,134 \mathrm{th}$ ）中央部付近 は, 左右の赤く着色された領域に比べて線の幅が狭いこ とに気付く。これは透水係数等の固有な値を決定してい るのは，より着色領域の広い左右の部分であるが，それ らを連結しているような形で存在する中央部の狭い亀裂 は, 応力の変化等による透水性の変化に対し支配的な存 在となりうることを示している。すなわち，応力(外力) の増加はより狭い亀裂から閉鎖させてしまうので，わず かな応力の増加により, 狭い領域が閉じてしまえば，系 全体の透水係数は大きく変化する。したがって, 岩石中
の流体移動を考える場合，大きな亀裂（というよりは孔 隙等）よりもむしろそれらを連結している亀裂を考慮の 対象にしておかなければならないと思われる。

\section{6. まとめ}

従来, 応力を負荷した状態での亀裂の可視化はその技 術的な困難さから，ほとんど手を付けられてこなかっ た。今回は三軸応力下に置かれた稲田花崗岩の供試体 を, 最大強度点を過ぎ, 荷重が変位とともに減少する変 形領域で応力制御を行いながら樹脂を注入し，樹脂の固 化後取り出して既述のような画像を得ている。応力によ って生じる亀裂のうち，地下水等の流体の移動，湿潤に 支配的な亀裂系の実態というのは従来末解明であり，本 手法による可視化技術により亀裂系を直接見ることは有 意義なことと思われる。

しかしながら，解明しなければならないのは，「流体 は，亀裂系の中をどのようなアルゴリズムで移動，湿潤 していくのか」という問題であり，この意味では今後解 明しなければならない問題が数多く存在することも事実 である。

著者らは現在，亀裂をより鮮明に抽出できるレプリカ フィルム3)を用いて，同じく 3 次元的に亀裂系を把握す る試みを行っている。この手法により，亀裂系の抽出は

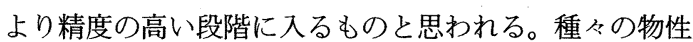
と亀裂との関連が明らかにされる日を待ち望んでいる。

\section{参 考 文 献}

1) 高橋 学, 薛 自求, 大和田朗, 石島洋二(1992): 青色顔 料を混合した樹脂によるポア観察について, 応用地質, Vol. 33, No. 5, pp. $294-306$.

2) 高野政明，三浦慶和，小堺加智夫，木暮 喬ほか(1994)： Application Visualization System(AVS) における脳，心臟 の三次元表示, THE 5TH JAPAN AVS CONFERENCE 講 演予稿集, pp. 197-205.

3）鈴木清史, 高橋 学(1994)：レプリカフィルムを用いた空 隙, 亀裂の可視化法, 応用地質, Vol. 35, No. 2, pp. 7778.

（1995年 4 月 26 日受付，1995年 5 月24日受理） 